\title{
EDITORIAL
}

\section{The Lancet, Gaza and academic publishing: defending political engagement}

Neil Arya ${ }^{1}$, Marion Birch, Frank Boulton, Shirley Hodgson, Mary Holdstock, Alan Ingram, Peter Karamoskos, Maria Kett, David McCoy, Michael Pountney, Simon Rushton, James Smith, Leo van Bergen, Elizabeth Willis

Editorial Board, Medicine, Conflict \& Survival, London, UK

"Those who control the present, control the past and those who control the past control the future."-George Orwell, 1984

In the summer of 2014, at the height of the Israeli Defence Force's 'Operation Protective Edge', The Lancet published 'An open letter for the people in Gaza' signed by Paola Manduca, Iain Chalmers, Derek Summerfield, Mads Gilbert and Swee Ang, on behalf of 24 signatories. The letter denounced what it called "the aggression of Gaza by Israel" and condemned the humanitarian impact of the incursion and of other Israeli actions such as the blockade on Gaza (Manduca et al 2014a). The publication of the letter stimulated vigorous debate with a further twenty published responses divided equally in either support of, or opposition to, the original letter (Lancet 2014). The letter was branded 'antiJewish bigotry, pure and simple' by some (Marmor \& Spirt 2014), while others claimed that the authors had failed to declare 'conflicts of interest' (Stall et al 2014; Wolf et al 2014).

Richard Horton, editor of The Lancet, later expressed regret for the "unnececsary polarisation" caused by the Manduca letter (Horton 2014). A subsequent report from The Lancet's independent Ombudsman concluded that the letter had some shortcomings (including missing references and its failure to acknowledge the use of armed violence by Palestinian factions), but noted that it had been written at a time of great tension and that efforts to correct these flaws had been made. The Ombudsman also noted that the authors' conflict of interest statements were incomplete and gave recommendations to prevent this from occurring again (Wedzicha 2014). However, the Ombudsman deemed that these issues were not considered sufficient grounds for withdrawal of the letter.

On the 15 $5^{\text {th }}$ of April 2015, Professor Sir Mark Pepys and colleagues, along with 395 (now over 750) signatories, wrote a letter to The Lancet's publisher Reed Elsevier asking it 'to behave ethically by retracting the Manduca letter, apologizing for its publication and ensuring that any further editorial malpractice at The Lancet is prevented' (Pepys et al 2015). Within twenty-four hours, a response to this complaint asking Reed Elsevier to

\footnotetext{
${ }^{1}$ Corresponding author. Email: narya@uwaterloo.ca
} 
stand firm in support of The Lancet, and backing the journal's decision to neither apologise for the decision to publish nor to retract the letter, was released by Professor Graham Watt and others. It has since gathered over 1000 additional supporting signatories (Watt et al 2015).

\section{Operation Protective Edge}

There is little doubt that 'Operation Protective Edge' inflicted a significant human toll. According to the UN Office for the Coordination of Humanitarian Affairs (OCHA 2015), 2,220 Gaza residents were killed (at least 70\% were civilians, including over 500 children) and 17,000 residents wounded. The official Israeli toll included 73 Israelis killed: 67 soldiers and 6 civilians (of whom one was a child, and one a migrant worker) with 469 Israeli soldiers and 255 civilians wounded. The psychological harm on both sides remains incalculable.

According to the Israeli human rights organization B'Tselem, 18,000 homes were destroyed or severely damaged (B'Tselem 2015), leaving 100,000 Palestinians homeless (Bachmann et al 2014). Physicians for Human Rights-Israel (PHR-I), Medact, Medico International and several other health organisations documented attacks on medical teams and facilities, and the denial of means of escape (ibid), whilst Human Rights Watch heavily criticised attacks that had hit schools as either disproportionate or without a proximate military target (Human Rights Watch 2014). Amnesty International further felt that Israel had "committed war crimes, including disproportionate and indiscriminate attacks on Gaza's densely populated civilian areas" (Amnesty 2014). Amnesty also condemned the 4800 rockets and 1700 mortars launched at Israel by Palestinian armed groups during the war, labelling these attacks "in breach of the laws of war", and indiscriminate in nature, despite the fact that they caused much less damage: "even in the hands of a highly experienced operator, a mortar round can never be accurate enough to hit a specific target" (Amnesty International 2015).

\section{Conflict of Interest and Bias}

The original Lancet letter was signed by 24 authors who described themselves as

"doctors and scientists, who spend our lives developing means to care and protect health and lives. We are also informed people; we teach the ethics of our professions, together with the knowledge and practice of it. We all have worked in and known the situation of Gaza for years" (Manduca et al 2014). 
This statement was criticised in a response on behalf of 1234 Canadian physicians (Stall et al 2014) as failing to represent full disclosure of "important conflicts of interest that are not consistent with their declaration of no competing interests", including the involvement of some authors with organisations believed by Stall et al to be "hostile to Israel".

A conflict of interest, according to The Lancet's guide for authors, "exists when professional judgement concerning a primary interest (such as patients' welfare or validity of research) may be influenced by a secondary interest (such as financial gain)" (Lancet 2015). Medical journals are usually concerned about corporate interests that may affect decision making. It seems hyperbole to call physicians taking either no financial support, or a pittance, to go to work for international NGOs, or in medical facilities, in Gaza a financial conflict of interest. The authors of the original letter argued this in a reply to their critics,

"We declared no conflicts since none of us has any relevant financial interests. We do have experience and affiliations enabling us to support Palestinian civil society and to engage in professional exchange ... We hope that most people will read our past work as evidence that we have considerable experience of the situation we described and commented upon" (Manduca et al 2014b).

While The Lancet's Ombudsman found a need for clarification of the rules and procedures related to 'conflict of interest', she found that "As experienced contributors to the medical and scientific literature, the authors should have been aware of the need to disclose, at submission, any financial or other relationships that could be perceived to affect their work." However, despite these criticisms, the Ombudsman stated that "I firmly believe that the debate about the conflict in Gaza would be the poorer if Manduca and coauthors' letter were to be withdrawn, and note that it has spurred a forthright debate in The Lancet" (Wedzicha 2014).

\section{Duties of Health Professionals and Medical Journals in Times of War}

A group of journals specialising in diabetes recently declared that "On the basis of our goals and principles, our respective journals will refrain from publishing articles addressing political issues that are outside of either research funding or health care delivery" (Cefalu et al 2014). This raises the question of whether health and health care, their multiple determinants and their distribution across populations, can ever be divorced from politics. Rudolf Virchow famously said in the 19th century that 'politics is nothing but medicine writ large' ('Politik ist weiter nichts als Medizin im Grossen') (Ashton 2006). Science and medicine always exist within a social and political context. We have observed the deep involvement of politics in health issues from HIV/AIDS to breast cancer, from neglected tropical diseases to pharmaceutical industry influence on the medical literature and public policy. The question should not be how we divorce science from politics, but rather how we manage these relations, which includes norms and processes such as transparency, peer 
review (for research articles), declaration of significant conflicts of interest, and right of reply.

As individuals serving on the Editorial Board of Medicine, Conflict and Survival - a journal which focuses directly on the relationship between conflict and health, and therefore frequently addresses explicitly political issues - we are naturally opposed to any suggestion that doctors and scientists should refrain from engaging in political debate, or that academic journals should not publish political pieces.

Health professionals have a responsibility to report violations of international humanitarian law and also to consider the political determinants of war and the causal chain that leads to the suffering they are witness. This inevitably necessitates an engagement in politicised debates related to the determinants of health, one of which is unequivocally violent conflict. While some have charged The Lancet with perverting the principles of science by allowing doctors and scientists to write about a political matter, we strongly believe that it is incumbent upon, and even unavoidable that, doctors and scientists engage with politics.

Several of the responses to the original letter raised the fact that Israeli medical personnel have treated Palestinian patients impartially and generously, including in times of conflict, and that many made considerable efforts to reach, treat, and care for the victims of Operation Protective Edge. This is indeed laudable and all health professionals will recognise this commitment to the alleviation of suffering as one of the core tenets of the medical profession.

\section{Editorial Judgment}

Other questions that are raised, especially for an Editor in relation to letters that are not as a rule subjected to peer review, are whether to publish correspondence on issues that are likely to be divisive, and to what extent a right to reply should actively be offered to the 'other side' in the event of disagreement. In this case The Lancet chose to publish the letter, but also provided a platform for those in disagreement with the original authors. Overall, we believe that this was an appropriate approach.

In fact it could be argued that The Lancet was too accommodating of those who wrote to criticise the original letter. A few of the responses made statements that one would have expected to be referenced. For example, if it is stated that 'political scientists agree' (Ahmed et al 2014), one would expect evidence of this. Some other statements clearly required some further explanation: "Israel has always allowed the passage of food , medicine and fuel into Gaza" (Wolf et al 2014) would need to address considerable evidence that 'always' is incorrect (SC \& MAP 2012). In such cases, the Editor has to walk a tightrope between facilitating discussion and identifying unsubstantiated comments. Despite a lack 
of referencing for some of these statements, and in parts of the original letter, we would again argue that The Lancet found the right balance.

Calls for the retraction of the original letter must also be explored. The Committee on Publication Ethics (COPE), which included Richard Horton and Richard Smith (former editor of the $B M$ ) ) as founders, developed guidelines on retraction (although it is important to note that these were designed for research rather than opinion pieces such as letters:)

"Journal editors should consider retracting a publication if:

- They have clear evidence that the findings are unreliable, either as a result of misconduct (e.g. data fabrication) or honest error (e.g. miscalculation or experimental error);

- The findings have previously been published elsewhere without proper crossreferencing, permission or justification (i.e. cases of redundant publication);

- It constitutes plagiarism;

- It reports unethical research" (Wager et al 2009).

In this instance, we believe that there is a need to distinguish between research articles and opinion pieces. If the conclusions drawn from a scientific paper are later found to be unreliable, the paper should be retracted. However retraction should not be applied to opinion pieces on the grounds of political disagreement. Neither, in such cases, should a journal's owners be asked to intervene to overrule the journal's editor.

Richard Horton is not one to shy away from controversial issues, and bravely opposed Elsevier's involvement in the arms trade, (The Lancet \& The Lancet's International Advisory Board, 2005) from which they divested two years later. He is well respected in the global health community, and has a track record of highlighting issues that have an impact on health.

Unfortunately obtaining objectivity during times of violent conflict is rarely straightforward, whether in Nepal, Syria, Sri Lanka, Libya, or Sudan. Journals have a responsibility to check facts and, in the case of scientific research, to seek independent peer review. Yet journals such as The Lancet also serve another function: as forums for professional, and inherently political, comment and debate. Indeed, we would question how The Lancet could operate as a socially-responsible journal without providing a platform for doctors, scientists, and other health advocates to speak out against threats to health, particularly when those threats affect children and civilians. Adherence to the rules and principles of science does not negate The Lancet's right to publish correspondence setting out moral, ethical and political opinions; nor should the latter undermine the primary role of a scientific journal to publish good research. 
We support Professor Graham Watt and colleagues, and urge Reed Elsevier to disregard demands for the withdrawal of the Manduca open letter, and the consequent curtailment of The Lancet's editorial freedom. 


\section{References}

Ahmed Q, Avidan A, Ciechanover A, et al (2014) Israel-Gaza conflict. The Lancet. Vol 384 e34-e37.

Amnesty International (2014), Amnesty International report 2014/15: Israel and Occupied Palestinian Territories [online] Available from: www.amnesty.org/en/countries/middleeast-and-north-africa/israel-and-occupied-palestinian-territories/report-israel-andoccupied-palestinian-territories/ (access verified 11th Mary 2015)

Amnesty International (2015), Unlawful and deadly: rocket and mortar attacks by Palestinian armed groups during the 2014 Gaza/Israel conflict [online] Available from: www.amnesty.org/en/documents/mde21/1178/2015/en/ (access verified 11th May 2015)

Ashton JR (2006), Virchow misquoted part-quoted, and the real McCoy. Journal of Epidemiology and Community Health. Vol. 60 (8): 671.

Bachmann J, Baldwin-Ragaven L, Hougen HP, et al. (2014), Findings of an independent medical fact-finding mission: Gaza 2014 [online] Available from: http://issuu.com/medico_international/docs/no_safe_place_gaza2014 (access verified 11th May 2015)

B'Tselem (2015) The legal and moral implications of the policy of attacking residential buildings in the Gaza Strip, summer 2014. B'Tselem: Jerusalem.

Cefalu WT, Nair KS, Seaquist ER, et al. (2014), ADA/AACE/EASD/TES statement in response to a recently published letter to the Editor in The Lancet and an editorial addressing the Israeli-Palestinian fighting in Gaza [online] Available from: www.diabetes.org/newsroom/press-releases/2014/adaaaceeasdtesstatement.html\#sthash.Ma2caFru.dpuf (access verified 11th May 2015)

Human Rights Watch (2014), In-depth look at Gaza schools attacks [online] Available from: www.hrw.org/news/2014/09/11/israel-depth-look-gaza-school-attacks (access verified 11th May 2015)

Horton R (2014), Geopolitical issues and responsibilities of medical and scientific journals. Rambam Maimonides Medical Journal. Vol. 6 (1): e0002.

Lancet, Lancet's International Advisory Board (2005), Reed Elsevier and the arms trade. The Lancet. Vol. 366 (9489): 868.

Lancet (2014), Published responses to the Gaza open letter [online] Available from: www.thelancet.com/gaza-letter-2014-responses (access verified 2nd May 2015) 
Lancet (2015), Declaration of interests [online] Available from: www.thelancet.com/lancet/information-for-authors/statements-permissionssignatures\#conflicts-of-interest (access verified 11th May 2015)

Manduca P, Chalmers I, Summerfield D, et al (2014a), An open letter for the people in Gaza. The Lancet. Vol. 384 (9941): 397-398.

Manduca P. Chalmers I, Summerfield D, et al (2014b) Israel-Gaza conflict: Authors' reply. The Lancet. Vol. 384: 746

Marmor BM, Spirt BA (2014), Israel-Gaza conflict. The Lancet. Vol. 384 (9942): 491.

OCHA (2015), Fragmented lives: humanitarian overview 2014. OCHA: Occupied Palestinian Territory, West Jerusalem.

Pepys M, Weinstein A, Zimmet P, et al (2015), Letter of complaint to Reed Elsevier: responsibility, honesty, and transparency are the essential basis of ethical medical and scientific publishing [online] Available from: http://concernedacademics.org (access verified 2nd May 2015)

Save the Children (StC) \& Medical Aid for Palestinians (MAP) (2012), Gaza's children: falling behind: the effect of the blockade on child health in Gaza [online] Available from: Available at: www.savethechildren.org.uk/resources/online-library/gazas-children-fallingbehind [accessed May 6th 2015]

Smith R (2014), No case for retracting Lancet's Gaza letter[online] Available from: http://blogs.bmj.com/bmj/2014/11/03/richard-smith-no-case-for-retracting-lancets-gazaletter/ (acess verified 11th May 2015)

Stall NM, Berger PB, Ray JG, et al (2014), Open letter for the people in Gaza - more than a military conflict. The Lancet. Vol. 384 (9941): 393-399.

Wager E, Barbour V, Yentis S, on behalf of the COPE Council (2009), Retraction guidelines [online] Available from: http://publicationethics.org/files/retraction\%20guidelines.pdf (access verified 11th May 2015)

Watt G, Chalmers I, Giacaman R, et al (2015), Response to the complaint to Reed Elsevier, publishers of The Lancet, by Professor Sir Mark Pepys and 395 colleagues [online] Available from: http://handsoffthelancet.com (access verified 2nd May 2015)

Wedzicha W (2014), Ombudsman's report on the letter by Manduca and others. The Lancet. Vol. 384 (9953): 1486-1487.

Wolf T, Brown DH, Aharony SM (2014), Israel-Gaza conflict. The Lancet. Vol. 384 (9942): 489-490. 